\title{
3 \\ Reading the Bodies of the Bounty Mutineers
}

\author{
Rachael Utting \\ Royal Holloway, University of London
}

On 15 October 1789, Lieutenant William Bligh wrote a damning letter to the British Admiralty in which he described the physical characteristics of the mutinous so-called pirates who cast him and 18 others adrift from the HMAV Bounty in a 7-metre open boat. Bligh and his launch crew covered nearly 4,000 nautical miles between Tofua and Coupang (now known as Kupang), in Timor, South-East Asia, in what is widely considered to be one of the most impressive and inspirational episodes in open-boat sea survival. They arrived at Coupang, weak and exhausted after six weeks at sea, on 14 June, 'perhaps a more miserable set of beings were never seen' who could 'not have existed a week or a day longer'. ${ }^{1}$ Remarkably, only one of their number had died, not from the rigours of the journey but from an attack by Islanders on the shores of Tofua, a small island where they had briefly found respite from their voyage (see Teriierooiterai, Chapter 1). A further four members died of disease in the ports of Coupang and Batavia (Jakarta). In the weeks and months after Bligh and his crew arrived in port, he was alight with indignation and penned a series of letters, both to the families of those mutineers

118 Aug 1789, ADM 1/1506 (9), The National Archives, London (TNA). This reference number covers all of Bligh's letters held in this file. Unhelpfully, several of these were written on the same day. Wherever possible dates have been added to aid archival research. 
who had betrayed his trust and to the authorities, outlining his version of events. In an attempt to vindicate himself for the loss of his ship in the obligatory court martial he knew he would face on his return to England, Bligh ensured every member of the launch crew signed an exculpatory affidavit witnessed by the governor of Batavia, William Adrian Van Este. ${ }^{2}$ This stated that Bligh was in no way responsible for the 'unforeseeable and unpreventable' loss of the Bounty and would 'use his utmost exertions to appear before their lordships and answer for the loss of his majesty's ship'. ${ }^{3}$ After recuperating at Coupang, Bligh and his remaining crew sailed to Batavia and, from there, in separate vessels on to England via the Cape of Good Hope. The day before he sailed on the Dutch packet SS Vlydte, Bligh wrote what was effectively a wanted poster for the mutineers. This revealing letter, now housed in the National Archives, London, intimately describes the bodies of those individuals whom Bligh sought to capture. ${ }^{4}$ Based on an earlier version written during the open-boat voyage, the letter outlines their markings in the form of tattoos, scars, effects of disease and wounds, and physical anomalies. These were described from Bligh's own memory and 'from the recollections of the persons with me, who were best acquainted with their marks'.5

This chapter does not investigate the guilt or innocence of those involved in the mutiny; this has been discussed at length in print and film over the last 200 years. Rather, its aim is to dissect Bligh's letter, to use the body as the primary focus of investigation and to discuss the physical characteristics of the Bounty mutineers. ${ }^{6}$ The document identified involuntary markings such as scars and wounds, and voluntary ones such as Polynesian tatau and Euro-American tattoos, the presence of which is a key factor in criminalising the mutineers within the Western consciousness. The chapter questions how these markings function

2 Greg Dening, Mr Bligh's Bad Language: Passion, Power and Theatre on the Bounty, Cambridge, Cambridge University Press, 1992, p 108.

318 Aug 1789, ADM 1/1506 (9), TNA.

418 Aug 1789 , ADM 1/1506 (9), TNA.

518 Aug 1789 , ADM 1/1506 (9), TNA.

6 The Bounty's crew members are identified in two groups: those that accompanied Bligh in the launch (the launch crew), and those that remained with the ship (the mutineers). This distinction is not indicative of guilt or innocence, and is provided merely for clarity within the text. The crew of the Bounty are broadly referred to as Euro-American, rather than their specific nationalities. This identifies them as falling under the umbrella of Western philosophy, teachings and religions whilst 'differentiating them from those who can be regarded as non-European in cultural and ideological terms' (S Williams Milcairns, Native Strangers; Beachcombers, Renegades and Castaways in the South Seas, Auckland, Penguin Books, 2006, p 16). Where quoting directly from the sailors, I have kept to their original, somewhat individual spelling and grammar. Any idiosyncrasies are their own. 
in a communicative context and highlights how, through acts of body modification, the mutineers attempted to reclaim their bodies from the subjectification of the British Royal Navy and integrate into Tahitian life.

\section{Bligh's marked men}

William Bligh's 'description list of the pirates' is one of several versions. The first was drafted in his notebook during the open-boat voyage when he and his subordinates certainly had plenty of time to trawl their collective memory for details, and one assumes their vitriol was at its highest. ${ }^{7}$ In addition to this, whilst recuperating in Batavia, Bligh wrote a version for Governor Van Este and gave another to the governor-general of India, Lord Cornwallis. These were to be distributed to 'their different settlements to detain the ship wherever she may be found' as 'it is impossible to say where a set of piratical people may go'. ${ }^{8}$ Van Este's copy was translated into Dutch and was clearly intended for the widest distribution possible. ${ }^{9}$ Bligh also took the opportunity to send a description of the mutineers to the newly formed Australian penal colony of Port Jackson. ${ }^{10}$ This illustrates the scope of such letters to migrate across geographic and linguistic boundaries and reach any number of European colonial outposts, spreading and reaffirming the view of what 'criminals' looked like, particularly ones who bore the distinct characteristics of a sailor. As maritime historian Marcus Rediker states, 'jack tar's body often gave away his line of work ... much to the delight of the press gangs that combed the port towns' ${ }^{11}$ His body was deeply tanned with a face that had 'withstood the most obstinate assaults of the weather', due to the nature of his work he often had broken or disfigured hands. He had marks of warfare and violence, a distinct way of speaking and walking, 'swinging [his] corps like a pendulum and believing it the most upright steady motion'. ${ }^{12}$ All of these distinct characteristics were found upon the bodies of the Bounty mutineers, from

7 W Bligh, 'Notebook and List of Mutineers', 1789, MS 5393, nla.gov.au/nla.ms-ms5393-2.

818 Aug 1789, ADM 1/1506 (9), TNA, p 26.

9 W Bligh, A Voyage to the South Seas, Undertaken by Command of His Majesty for the Purpose of Conveying the Breadfruit Tree to the West Indies in His Majesty's Ship the Bounty, London, P Wogan, 1792, p 362 .

10 Sven Wahlroos, Mutiny and Romance in the South Seas; A Companion to the Bounty Adventure, Massachusetts, Salem House Publishers, 1989, p 89.

11 M Rediker, Between the Devil and the Deep Blue Sea. Merchant Seamen, Pirates, and the Anglo American Maritime World, 1700-1750, Cambridge, Cambridge University Press, 1987, p 12.

12 N Ward, 1756, quoted in Rediker, 1987, p 11. 
the bow-leggedness of Fletcher Christian to the damaged arm of Henry Hillbrant whose 'left arm [is] shorter than the right, [where it] has been broke', to the 'dark' or 'high brown' complexions of Edward Young and John Millward amongst others. ${ }^{13}$

Although Bligh's letter forms part of a chain of private correspondence, details of the mutiny soon appeared in the national press. Bligh's racial terminology was typical of that used in the emerging print culture of the era. The newspapers used a rich visual language to describe individuals at large, whether runaway slaves, servants, military absconders or everyday criminals. In order to facilitate an arrest, this necessarily concise language contained a 'verbal shorthand' focused on those features most easily recognisable by the public. ${ }^{14}$ The height, skin colour and demeanour of miscreants were obvious starting points on which to build a public image of a formerly private body. ${ }^{15}$ Bligh's letter is in keeping with this literary tradition, listing these attributes for each mutineer in addition to their ages, scars, wounds and tattoos. In order to describe skin tone, he used a palette ranging from 'sallow' to 'pale' and 'high brown' to 'dark brown' and, finally, 'blackish', which he reserved for Christian. These terms were not necessarily indicative of ethnic background; darkened skin was the mark of career sailors. It was an easily recognisable side effect of their profession. They were terms that could also be used to indicate the sense of dirt and moral laxity associated with the British lower classes from which the bulk of maritime workers were drawn. It was within these lower classes that tattooing was principally associated, having been used to mark criminals and deserters from the British army (a practice begun in 1717 and not rescinded until 1879) and, with increasing popularity, nomadic social groups such as soldiers and sailors. ${ }^{16}$ Within the consciousness of the literate upper classes the fact that tattooing had been used for largely

1318 Aug 1789, ADM 1/1506 (9), TNA.

14 G Morgan \& P Rushton, 'Visible Bodies: Power, Subordination and Identity in the EighteenthCentury Atlantic World', Journal of Social History, vol 39, no 1, 2005, p 42.

15 The term 'private' is used with restraint as by the late 18th century the bodies of the populous were undergoing increasing scrutiny from bureaucratic sources. Workhouses, hospitals, asylums and jails kept increasingly detailed records for public and private uses. See Douglas Hay, Peter Linebaugh, John G Rule, EP Thompson \& Cal Winslow (eds), Albion's Fatal Tree: Crime and Society in EighteenthCentury England (London, Allen Lane, 1975); H Maxwell Stuart \& J Bradley, "Behold the Man": Power, Observation and the Tattooed Convict' (Australian Studies, vol 12, no 1, 1997, pp 71-97).

16 See, for example, the 'Branding tool for marking deserters, London, 1810-1850' in the collection of the Science Museum, London, obj no A627067, broughttolife.sciencemuseum.org. uk/broughttolife/objects/display?id=92953 See also, Ira Dye, 'Tattoos of Early American Seafarers, 1796-1818' (Proceedings of the American Philosophical Society, vol 133, no 4, 1989, pp 520-21). 
punitive purposes encouraged an association between tattoos and the criminality of the proletariat masses. In addition to this, the popularity of voyage narratives with their descriptions and illustrations of 'painted natives' ensured that indigenous tattoos had become the sign of the exotic other, the identifying mark of natives and savages. ${ }^{17}$ That the Bounty mutineers were described as being so heavily tattooed only incriminated them further; as if the act of mutiny wasn't bad enough, they had taken up with island women and gone native. The General Evening News reported:

The most probable conjecture is, that, being principally young men they were greatly fascinated by the Circean blandishments of the Otaheitean women, they took this desperate method of returning to scenes of voluptuousness unknown, perhaps in any other country. (16 March 1790)

These men illustrated the power of island living to subvert the supposedly superior Western mind. Their crimes were made worse by the fact that, as white men, they had known Christian salvation and willingly chose to throw it off. In contrast with the unmarked, light-skinned and clothed Christian body, native skin was dark, tattooed and uncovered. By darkening their skin with marks of 'cultural treason' the Bounty sailors confused the clear definition of coloniser and colonised within the Western mind. ${ }^{18}$ That Bligh reserves the term 'blackish' to describe Christian indicates his antipathy towards the mutineer. This terminology, in addition to the statement that Christian sweated profusely and 'soils everything he touches', could be read as an attempt to portray him as a physically and morally degenerate character. Comparison of the version written in the launch notebook and the later one to which this chapter refers reveals minor deviations between the two documents, which indicates that the passage of time and memory had led Bligh to

17 In 1595, almost 200 years before Sir Joseph Banks, naturalist on Cook's voyage, described Polynesian tattooing, the Spanish navigator Pedro Fernandez de Quiros observed that the inhabitants of Fatu Hiva in the Marquesas were 'naked, without any part covered: their faces and bodies in patterns of a blue colour, painted with fish and other patterns' (Quiros, 1595; quoted in B Douglas, "CCurious Figures": European Voyagers and Tatau/Tattoo in Polynesia 1595-1800', in N Thomas, A Cole \& B Douglas (eds), Tattoo: Bodies, Art and Exchange in the Pacific and the West, London, Reaktion Books, 2005, p 33). In 1590 (five years prior to de Quiros' description), the engravings of Theodore de Bry were published in Thomas Harriot's A Briefe and True Report of the New Found Land of Virginia. Based upon John White's original watercolours of New World Indians, these engravings included imagery of indigenous 'types', including tattooed 'Picts of Ancient Britain', and had catapulted visions of tattooed men and women into the public eye (see K Sloan, A New World: England's First View of America, London, British Museum Press, 2007). This textual reporting of tattoos was also reinforced by the exhibition of individuals. Beginning in the late 16th/early 17th century, there were occasional and much publicised exhibitions of tattooed 'natives' who were kidnapped or coerced from their New World homes.

18 Williams Milcairns, 2006, p 30. 
change his descriptions of Christian. In the launch notebook, Christian is described as having a dark swarthy complexion; in the later versions, this is amended to a 'Blackish or very dark brown Complexion'. This subtle shift of wording indicates a level of embellishment that should make us wary of the veracity Bligh's descriptive language. Bligh is in no way impartial and issues of memory, audience and narrative reliability must be acknowledged when reviewing historical source material such as this. With regard to reliability, however, if his letter were not an accurate description of the bodies (rather than demeanour or colour) of the runaway sailors, then it would fail in its primary purpose, which was to allow them to be identified with sufficient certainty as to lead to their apprehension. Their arrest and subsequent trial would exonerate Bligh from any responsibility for the mutiny and, therefore, the failure of the voyage. ${ }^{19}$ We can only assume that Bligh and his co-castaways are honest as far as possible about the physical marks (scars, wounds, tattoos) they mention; however, their assertions that certain mutineers were 'dark', 'raw boned' or had a 'rather a bad look' should be treated with caution. After all, how does one define a 'rather bad look'?

\section{Eighteenth-century sailor tattoos}

William Bligh's description is of typical sailors of the late 18th century, men physically altered by their vocational and pathological experiences. The list of injuries, largely compliant with a seafaring vocation (although of course other interpretations are possible) includes multiple broken or disfigured fingers or toes and damaged limbs. Marks of violence include scars from stabbing and a musket-ball wound. The impressive list of diseases that left their marks on the bodies ranges from multiple cases of small pox, scrofula (tuberculosis of the lymph glands, known as the king's boil), rotten or missing teeth (a symptom of the poor dental hygiene of the era but also a side effect of scurvy), to the excessive sweating of Fletcher Christian, which is possibly the result of hyperhidrosis. ${ }^{20}$ To differentiate these men from the thousands of other sailors exhibiting

19 As Captain Cook's former sailing master on HMS Resolution, Bligh was hopeful of his future prospects within the Navy. Cook's untimely death made it imperative for Bligh's career that Sir Joseph Banks' breadfruit mission was a success. Only the successful court martial of the mutineers would ensure Bligh's reputation remained intact. See Caroline Alexander, The Bounty: The True Story of the Mutiny on the Bounty (London, Harper Perennial, 2003, pp 46-48).

20 For a discussion of Christian's possible medical condition, see D Williams, Mutiny on the Bounty \& Pandora's Box (Lulu.com, 2015). 
similar marks of disease and violence, Bligh relied on the scale and variety of their Euro-American tattoos and their adoption of Tahitian tatau. The following information is extracted from Bligh's letter.

Table 3.1: Tattooed markings on the bodies of the 25 Bounty mutineers

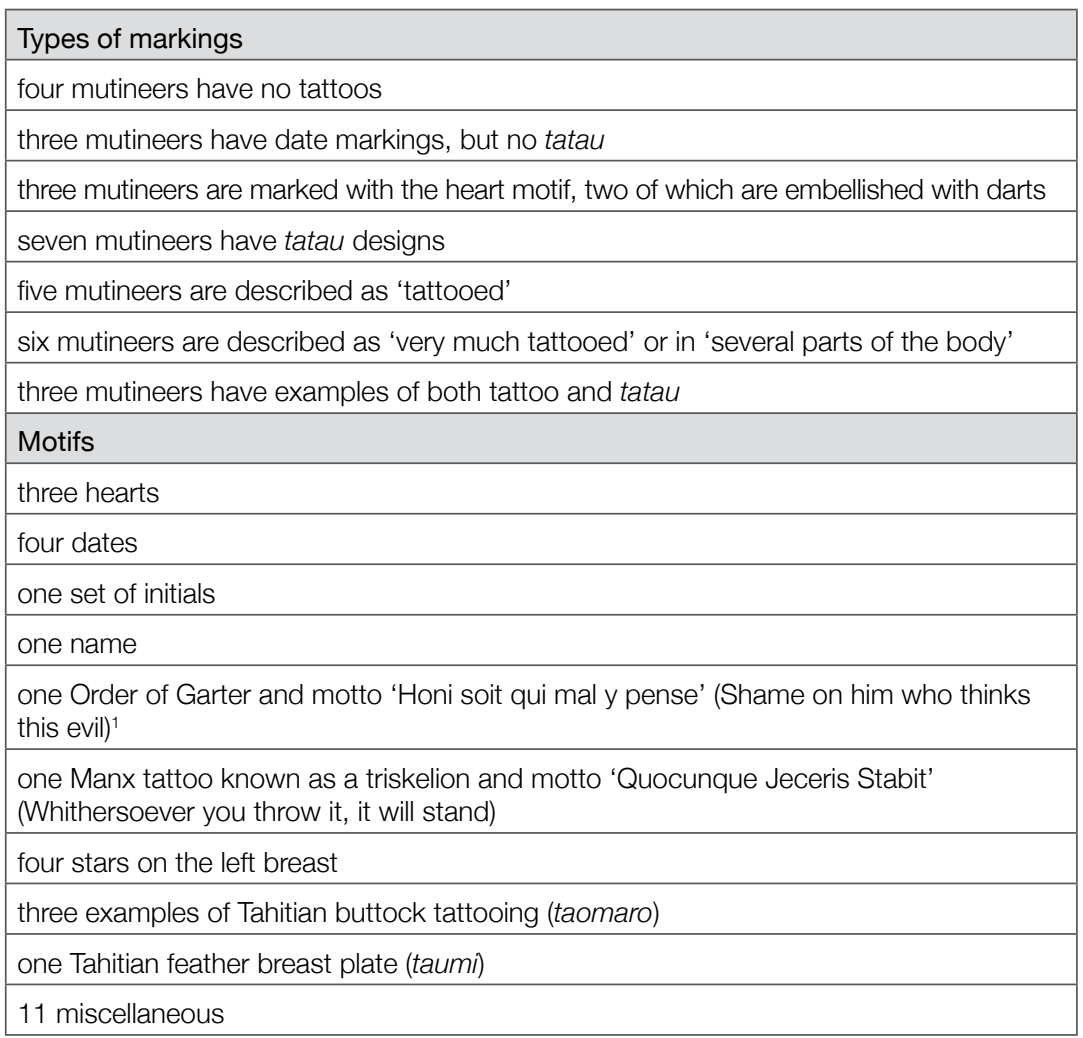

${ }^{1}$ For information about the Order of Garter, see www.royal.uk/order-garter.

The onomatopoeic Polynesian term tatau was introduced to the English language in the late 18th century via the early contact voyage narratives of Samuel Wallis, Louis-Antoine de Bougainville and James Cook (and the evidence upon the skin of Cook's crew). This was not the origin of the activity of tattooing, however, only of the name. ${ }^{21}$ The Anglicised term tattoo became synonymous with a pre-existing practice previously

21 This theory is supported in the following works: J Caplan (ed), Written on the Body: The Tattoo in European and American History (London, Reaktion Books, 2000); CP Jones, 'Stigma: Tattooing and Branding in Graeco-Roman Antiquity' (Journal of Roman Studies, vol 77, 1987, pp 139-55); SP Newman, 'Reading the Bodies of Early American Seafarers' (The William and Mary Quarterly, 3rd series, vol 55, no 1, 1998, pp 59-82; Dye, 1989, pp 520-54). 
known to Euro-Americans by terms such as 'inking' or 'sailor's marks'. The stereotypical sailor's marks of the era included religious motifs such as angels and crosses, and maritime imagery such as anchors, ships, fish and stars. Also included were images of hearts, dates, Masonic symbols and national emblems such as eagles or flags. ${ }^{22}$ Although voyage narratives reinvigorated the activity, the tattooing of seafarers is thought by some to be a 'common and well-established practice at the time of Cook's voyages and probably long before. ${ }^{23}$ That 84 per cent of the mutineers described by Bligh had tattoos (whether acquired on the Bounty voyage or not) indicates an overwhelming interest in body modification throughout the ship's company, from the below decks' able seamen to the quarterdeck, the exclusive preserve of the officers and gentlemen. If this level of tattooing is representative of a trend amongst late 18th-century sailors, it seems to support the theory that tattooing was already a well-established practice amongst seafarers.

Historian Ira Dye carried out an exhaustive analysis of American seafarers and their tattoos through two sets of primary data extending over 22 years from 1796-1818. ${ }^{24}$ These two sources - the Philadelphia Seamen's Protection Certificate applications (SPC-A), held at the US National Archives; and the General Entry books of American prisoners of war, 1812-15, held at the National Archives, London - represent the only detailed data on American seafaring tattooing of that period. ${ }^{25}$ SPC were issued as proof of nationality for American sailors (or those that had been naturalised), who wished to avoid being forcibly impressed into the British Navy. The British authorities argued that British citizenship was enduring and, as such, American individuals could justifiably be impressed when the Navy was shorthanded. It was in the sailors' interest to ensure that their defining features were clearly and accurately described, including their tattoos. This has left historians with a wealth of body historiographies to analyse with regard to ages, heights, injuries, literacy and body modification. ${ }^{26}$ Dye's research into the 9,772 surviving SPC-A records (38 per cent of the total issued) shows that 979 individuals were

\footnotetext{
22 Newman, 1998, pp 69-71.

23 Dye, 1989, p 523.

24 Dye, 1989, p 523. The multicultural nature of maritime communities, whether based at sea or at liberty on land, created the perfect breeding ground for tattooing and shared tattoo iconography to spread. It is likely, therefore, that the tattoo designs of American sailors were broadly speaking comparable with their European counterparts. The obvious exception is that British bodies may have displayed patriotic tattoos, such as James Morrison's Order of the Garter, and lacked the American revolutionary tattoos sported by some older Americans.
}

25 Dye, 1989, p 532.

26 Newman, 1998, p 60. 
tattooed with a total of 2,354 tattoos. Of these 979 men, 40.1 per cent had only one tattoo (usually their initials) and the number of men with multiple tattoos dropped sharply as tattoo numbers increased. ${ }^{27}$ Between 1796 and 1803, 20.6 per cent of sailors were marked and, by 1801, this figure had increased to 27.8 per cent. ${ }^{28}$ Amongst the 2,354 sailor tattoos identified by Dye, there is not one tatau or mark identified as being of Polynesian or, to use mutineer Peter Heywood's term, 'curious' origin. ${ }^{29}$ Although it is known that some members of Cook's crew acquired markings in Polynesia, there is limited evidence to suggest that this activity was on the same scale as shown by members of the Bounty crew. The adoption of Tahitian tatau amongst the crew of the Bounty, therefore, represents an evolution in the practice of early sailor tattooing as it deviated from the conventional format of the era, which was limited in the number of designs and bodily locations.

\section{Island interactions: Tattoos and tatau}

Table 3.2: Description of mutineer's tattoos

\begin{tabular}{|l|l|l|}
\hline 1 & Fletcher Christian & Star on left breast, tatau on backside \\
\hline 1 & George Stewart & $\begin{array}{l}\text { Star on left breast, tatau on backside, heart with darts } \\
\text { and date on arm } \\
\text { Very much tattooed, three-legged emblem of Isle of Man } \\
\text { and motto }\end{array}$ \\
\hline 2 & Edward Young & $\begin{array}{l}\text { Heart with dart, date 1788 [or possibly 1789] and initials } \\
\text { EY }\end{array}$ \\
\hline 4 & Charles Churchill & Tattooed in several parts of the body \\
\hline 1 & James Morrison & $\begin{array}{l}\text { Star on left breast, Order of the Garter, Knight of Garter } \\
\text { and motto }\end{array}$ \\
\hline 3 & John Mills & Not tattooed \\
\hline 1 & John Millward & Tatau under pit of stomach, a Tahitian breast plate \\
\hline 4 & Matthew Thompson & Tattooed \\
\hline 4 & William McKoy & Tattooed \\
\hline 1 & Matthew Quintal & Tatau on backside and 'other places' \\
\hline 4 & John Sumner & Tattooed in 'several places' \\
\hline 4 & Thomas Burkitt & Very much tattooed \\
\hline
\end{tabular}

27 Dye, 1989, pp 535 (number of tattoos), 542 (information on initials).

28 Dye, 1989, p 533.

29 Edward Tagart, A Memoir of Captain Peter Heywood, R.N., with Extracts from his Diaries and Correspondence, London, E Wilson, 1832, p 82. 


\begin{tabular}{|l|l|l|}
\hline 1 & Isaac Martin & Star on left breast \\
\hline 4 & William Muspratt & Tattooed in 'several places' \\
\hline 4 & Henry Hillbrant & Tattooed in 'several places' \\
\hline 4 & Alexander Smith & Very much tattooed \\
\hline 4 & John Williams & Tattooed \\
\hline 4 & Richard Skinner & Tattooed \\
\hline 2 & Thomas Ellison & Name, October 25th 1788 on arm \\
\hline 4 & William Brown & Tattooed \\
\hline 3 & Michael Byrne & Not tattooed \\
\hline 2 & Joseph Colman & Heart tattooed on arm, also the date 5-7-772 \\
\hline 3 & Thomas Mclntosh & Not tattooed \\
\hline 3 & Charles Norman & Not tattooed \\
\hline
\end{tabular}

$1=$ has tatau

2 = has tattoos

$3=$ not tattooed

$4=$ miscellaneous

2 The information in this table is extracted from Bligh's letter to the Admiralty, 15 October 1789 (ADM 1/1506 [9], TNA), in keeping with Bligh's order of mutineers. The specifics of Coleman's tattoo and details of his previous voyage with Cook are taken from Alexander, 2003, p 250.

Table 3.2, extracted from William Bligh's letter, outlines the range of imagery inscribed upon the mutineer's skin and the textual details of the marks described. It indicates the scale of body modification amongst the mutineer crew. Of the 25 mutineers, only four had not indelibly inked their skin. ${ }^{30}$ The iconography falls into two groups, which this chapter refers to separately. These are tattoos: marks originating from the Euro-American design spectrum; and tatau: marks that Bligh identifies as being of Polynesian origin. Tattoos range from hearts, alphanumeric characters and marks of regional and national affiliation, such as Peter Heywood's Isle of Man emblem (the Manx triskelion) and James Morrison's symbol of the Order of the Garter and associated French motto. Tatau include Able Seamen John Millward's 'Taoomy or Breast plate of Otaheite'; the extensive buttock tattooing known as taomaro,

30 It is striking that, of the four members who Bligh indicated were innocent of mutiny, 'these two last McIntosh and Norman declared as Coleman had done [that they had taken no part]. Michael Byrne, I was told had no knowledge of what was doing'. Only one of these four crew members, Joseph Coleman, had a tattoo; it was an inoffensive heart and date. The other three had neither tattoos nor tatau. They were described as both innocent and unmarked. I question how far Bligh felt, or was using, the presence of tatau as a marker of criminality amongst his mutineers. 
which appear on the bodies of Fletcher Christian, George Stewart and Matthew Quintal; and the star motif found on the left breast of Christian, Stewart, Morrison and Isaac Martin. This star motif is identified as being of Tahitian origin because it was also adopted 15 years before by the crew of James Cook's ship, HMS Resolution. There are also ambiguous references to individuals being 'very much tatowed' or 'Tatowed on Several places'. These are tantalising descriptions that offer insight into the scale of sailor tattooing in the late 18th century, but lack the description adequate for useful analysis. Therefore, the mutineers described as such are set aside to concentrate on those who bear clearly defined markings.

\section{Second skins}

The Tahitian tattooing process was clearly not a ritual to be undergone lightly; early reporters of the practice commented on the extreme levels of pain endured, ${ }^{31}$ which were so great that to undergo the operation 'a stranger would suppose it was doing $[\mathrm{sic}]$ against their will and that they were forced to suffer it contrary to their inclinations'. ${ }^{32}$ William Bligh's description, discounting the 11 'very much tattooed' individuals, indicates three - Fletcher Christian, George Stewart and Mathew Quintal - who had aquired taomaro. Taomaro consisted of a series of extended arches stretching across the hips and buttocks, as can be seen on the body of the Tahitian woman in Figure 3.1, a detail from a painting by William Hodges draughtsman on Cook's second voyage.

Within the Tahitian tatau tradition, extensive buttock tattooing was a way of controlling the delicate balances of tapu (sacredness) and mana (potency) associated with the childhood phase of life. ${ }^{33}$ The tattooing of

31 JC Beaglehole (ed), The Endeavour Journal of Sir Joseph Banks 1768-1771, vol 2, Sydney, Angus and Robertson Ltd, 1963; Tagart, 1832.

32 James Morrison, The Journal of James Morrison, London, Golden Cockerel Press, 1935, p 21.

33 Any discussion of tatau must also incorporate the principles of mana and tapu, both terms that lack a direct translation. Mana is described as:

Not so much a mystical abstract power which people possess, but rather an efficacy manifested in specific outcomes such as fertility, health or success. It is a means by which divinity manifests its presence in the world through particular persons and things. Being of divine origin, mana is a problematic potency, dangerous, life creating and life destroying, and must be managed with care. (S Hooper, Pacific Encounters: Art and Divinity in Polynesia 1760-1860, London, British Museum Press, 2006, p 37)

Тарu was a state of being in opposition to mana. It referred to things that were 'restricted', 'holy', a 'state of a person, a thing, a place or a time period when mana is present' (Hooper, 2006, p 37). Any contact with tapu objects or individuals must be avoided or controlled. 
a taomaro in adolescence was part of a complex process of deconsecrating rites, known as $a m o^{\prime} a$. The performing of $a m o^{\prime} a$ rites during early adolescence acted to progressively lessen tapu status associated with this phase of life. Amo'a allowed children to engage in increasingly higher levels of social relationships, ultimately marking the end of childhood and the availability for sexual relations and fertility. ${ }^{34}$ James Morrison noted that girls 'never conceive themselves company for weomen - being only counted as children till they have their tattowing done'. ${ }^{35}$

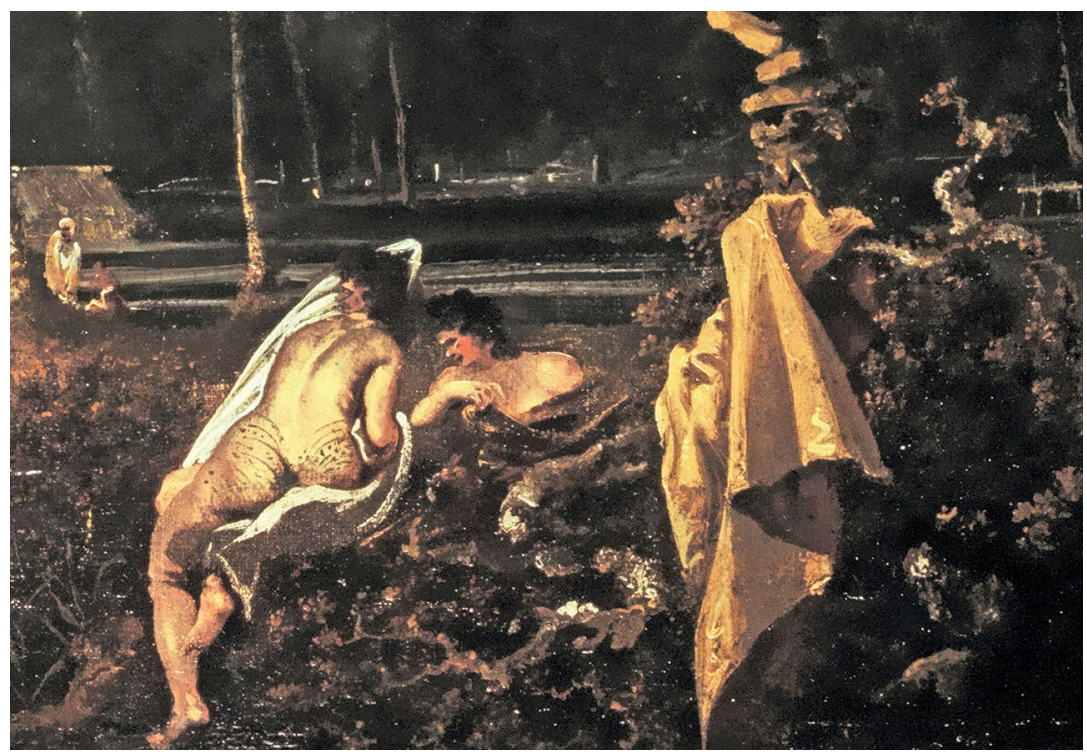

Figure 3.1. Detail from William Hodges, $A$ View taken in the bay of Oaite Peha [Vaitepiha] Otaheite [Tahiti] ('Tahiti Revisited'), 1776.

Source: National Maritime Museum, collections.rmg.co.uk/collections/objects/13872.html.

The tattooing of taomaro was described at length in Morrison's diary:

The Hips of Both sexes are Markd with four or five Arched lines on each side, the Upper most taking the whole sweep of the Hip from the Hip bone to the Middle of the Back where the two lines Meet on one, which is drawn right a Cross from one hip to the other and on this all the other lines begin and end; under this Center line are generally four or five more, sweeping downwards, but Most Woeman have that part blacked all over with the Tattowing. ${ }^{36}$

34 M Kuwahara, Tattoo: An Anthropology, Oxford, Berg, 2005, pp 12, 35.

35 Morrison, 1935, p 221.

36 Morrison, 1935, p 221. 
According to anthropologist Alfred Gell, author of Wrapping in Images (1993) - the seminal work on the subject of Pacific tattooing - the name translates as tao (spear) and maro (girdle) indicating the protective capacity of taomaro. ${ }^{37}$ Any contact with tapu objects or individuals had to be avoided or controlled. Cosmological tattooing such as taomaro involved protecting or controlling the principles of $p o-$ the world of darkness, the gods and 'sacredness' - from ao - 'the world of light, of the senses, and of ordinary existence'. ${ }^{38}$ These opposing cosmological states were created by the god Ta'aroa who, by cracking his shell, created the ao world. As Gell suggests, Tahitian cosmology 'was centred on the idea of crusts and shells, so that all phenomenally real things were defined as shells within shells, and so on'. ${ }^{39}$ The skin represented an interactive zone upon which tatau markings provided an additional shell. These markings placed the wearer within Tahitian social hierarchy, which consisted of ari $i$ (the chiefly class descended from gods), yeomen and commoners. Specific tatau also indicated that the bearer belonged to one of the eight grades of the revered Arioi religious group.

As the body is born with skin and therefore pre-wrapped, tattooing represents the creation of a second skin encasing the mana within the body whilst protecting individuals and keeping Tahitian society in the appropriate balance of $p o$ and $a o$. This boundary status on the skin is described as a way of wrapping the body, not so much to form a secondary skin as to be a skin itself. ${ }^{40}$ Therefore tatau has a trans-dermal quality, able to be both within the skin and on the skin. For the Tahitian, 'not just the person, but the whole world was a skin, a fragile integument, through which a precarious two-way traffic had to be maintained'. ${ }^{41}$ This dichotomy of wrapping and revealing - controlling the visibility of the flesh - did not go unnoticed by the mutineers. As Morrison described in his diary, Fletcher Christian clearly appreciated this as, post-mutiny, he had the studding sails cut up to make uniforms for all hands:

Observing that nothing had more effect on the minds of Indians as a uniformity of Dress. Which by the by has its affect among Europeans as it always betokens discipline especially on board British Men of War. ${ }^{42}$ (Morrison's own emphasis) 
The fact that the crew had to be dressed around their superiors, just as the Tahitian had to be uncovered in the presence of their chiefs, indicates that the importance of wrapping permeated throughout Tahitian culture. The wrapping of individuals in bark cloth, sometimes great quantities of it, was an integral part of the ritualised activities at key events such as birth, dancing, tattooing, fighting and ultimately death. It was also part of the taio exchange ritual in which individuals with whom friendship relationships were expressed in name exchange, would wrap their taio in bark cloth. Tinah, Bligh's taio, wrapped him in a 'large quantity of cloth, we joined noses and exchanged name, he taking the name of Bligh ... and I that of Tinah'. ${ }^{43}$ Taio exchange relationships integrated Bligh and many of the crew into Tahitian life and, as it would transpire, politics. By allowing taio partners reciprocal access to goods, labour and kinship relations in the form of adoption and sexual relations with a taio partner's wife, the custom of name exchange blurred the lines of personal identity and ownership. ${ }^{44}$ Bligh makes it clear in the ship's log, however, that the relationship could be a little one-sided: 'I am sorry to say my friend Tynah [Tinah] although I have loaded him with riches is not very grateful in return. ${ }^{45}$ Tinah made repeated requests for arms and it was the access to weaponry afforded to the Islanders by these relationships that ultimately changed the face of island politics (see Largeaud-Ortega, Chapter 4).

Tattooing and name exchange represented a means to avoid transgressing tapu, and exposing oneself to potentially destructive mana, but on a wider societal level it was a way of maintaining social cohesion and reproduction. It was a way of keeping the Tahitian world in balance. Morrison suggests that a person who was deficient of tatau was 'publically reproached'. ${ }^{46}$ His description of taomaro is interesting because he states that the design, in parts, is open to personal choice:

evry one pleases their own fancy in the Number of lines or the Fashion of them, some making only one broad one while others have 5 or 6 small ones ornamented with stars and sprigs \&c. ${ }^{47}$

43 Extract from the logbook HMS Bounty, kept by Captain W Bligh, 16 Aug 1787- 20 Aug 1789

(Bounty, Log), 28 Oct 1788, ADM 55/151, TNA.

44 Kuwahara, 2005, p 46.

45 Bounty, Log, 18 Nov 1788, ADM 55/151, TNA.

46 Morrison, 1935, p 221.

47 Morrison, 1935, p 221. 
The indication that there was a degree of choice in design suggests that it was not just the design that carried the protective capacity, but the application of the tatau itself - the ritual creating of Gell's second skin. The women trading sex and island produce for Western goods on the Bounty's arrival were not peturbed by the sailors' lack of taomaro. As Bligh wrote in the ship's log, the Tahitians 'crowded on board in vast numbers ... and within minutes I could scarce find my own people', so we assume that the benefits of trade outweighed the fear of the foreigner's uncontained mana. ${ }^{48}$ Without tatau, however, the crew were unstable entities. To leave them unmarked was to risk leaving the tapu associated with individuals who were essentially alien beings from across the sea unrestrained and dangerous. The interaction between the tattooist (tahu'a) and a sailor involves the transfer of motif onto the body and the absorption of the stranger into Tahitian life: it can be seen as a transformative ritual in which the visible structure supported an invisible one. The amalgamation of the forces of the land (Tahitians) and the sea (foreigners) through marriage alliance or sociopolitical office was a recognised practice. It produced a stronger society in terms of its mana because the whole is more than the sum of its parts; the forces of Sea and Land were united to create a stronger entity. The tattooing of the crew represented a means of integrating them into Tahitian life, thereby facilitating social cohesion. It can also be seen as an assertion of indigenous agency: tattooing the sailors or encouraging them to engage in taio exchange pacts allowed easier access to tradable goods and, more importantly, firepower. The deeply asymmetrical relationship of boat versus beach was levelled slightly by the act of name exchange and the adoption of tatau.

In January 1789, three sailors deserted Bligh's crew, demonstrating that several crewmembers were committed to adopting Tahitian life. Charles Churchill, William Muspratt and Millward must have relied on a significant amount of help from their Tahitian friends and their taio. They deserted at a time when most of the sailors were living at ease, some ashore. It was several months before they were due to leave and, given departure was not imminent, the log of the Bounty informs us that Bligh allowed women to stay with the men on board the ship at night. ${ }^{49}$ The men's food was not rationed and life was significantly more pleasant than during the difficult 
voyage to Tahiti. ${ }^{50}$ The deserters' planned escape, relying on indigenous help and language skills, suggests a considerable level of interaction with their hosts. According to Bligh, Millward had an extensive tatau on his lower abdomen in the form of a Tahitian breastplate, or gorget, known as a taumi. See Figure 3.2 for an example.

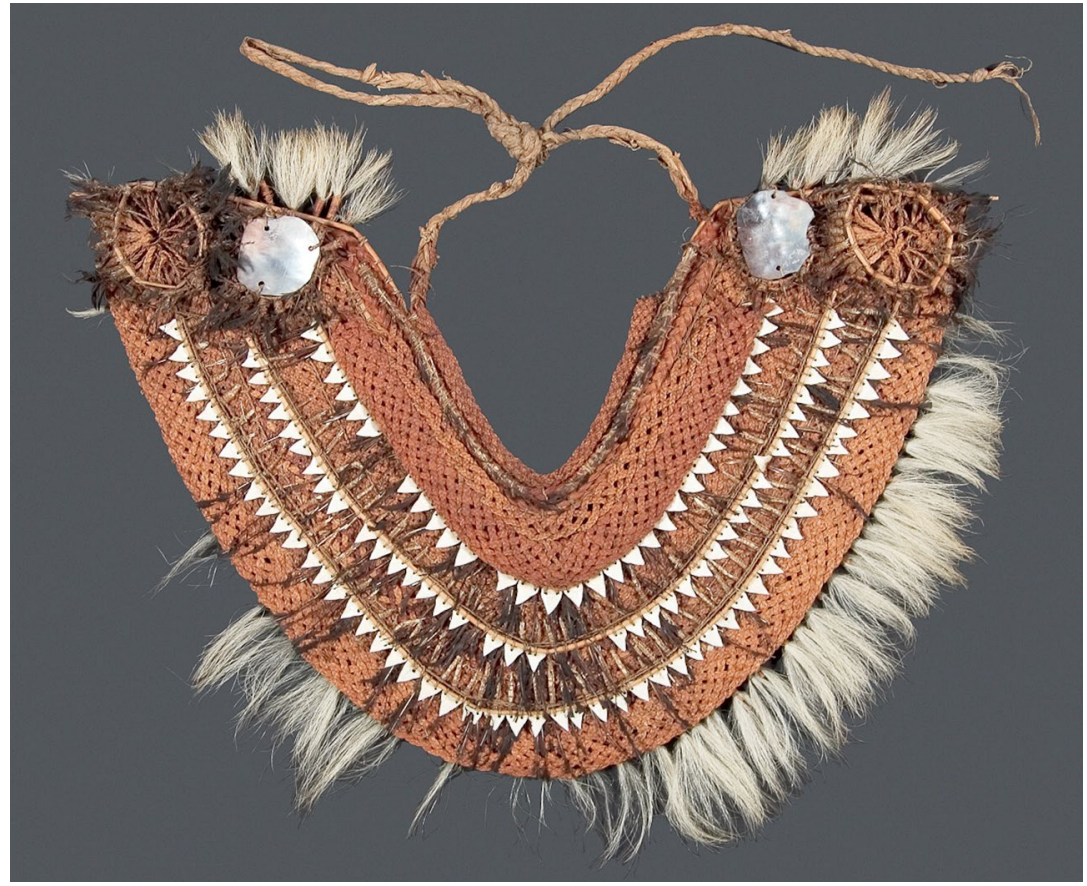

Figure 3.2. Tahitian Gorget (taumi). Crescent-shaped breast ornament decorated with feathers, hair and shark's teeth.

Source: 1887.1.392, Pitt Rivers Museum, University of Oxford.

The taumi was a visually striking breast adornment worn by warriors. Its distinctive shape was thought to represent the jaws of a shark and imbued the wearer with the qualities of said animal. ${ }^{51}$ These high-status objects covered most of the bearer's chest and were often highly decorated with feathers and shark teeth. Taumi formed part of the exchange relations played out between high-status Islanders and senior visiting mariners. During his investiture as an elite 'Erree of Oparre', Bligh was offered 'a Tahaumee or Breast plate' in addition to long swathes of red-stained

50 Bligh outlined this ordeal in a letter to the Admiralty from the Cape of Good Hope on 24 May 1788 (ADM 1/1506 (9), TNA).

51 Hooper, 2006, p 185. 
bark cloth. ${ }^{52}$ Cook was also given a taumi when he was on Tahiti. ${ }^{53}$ Taumi were not normally found (or not recorded by European visitors) within the tatau design lexicon. The adoption of this design by Millward, therefore, directly allied him with the material culture of a warrior and represented a particularly assertive statement in self-representation. It is suggested that this use of the taumi tatau is an example of what Gell describes as 'scheme transfer', a tradition within Polynesian tattooing of the adoption/adaptation of a material object into tatau designs. ${ }^{54}$ While the Tahitians developed new tatau iconography based on Western goods - such as guns, animals, swords and compasses - Tahitian designs were being adopted by the Euro-Americans.

All three deserters were soon recaptured. Millward and Muspratt were sentenced to four dozen lashes and Churchill to two dozen, to be dealt out on two separate occasions. Considering desertion was a capital offence, all three can be said to have got off lightly. The sailors would have been stripped to the waist and lashed to a latticed frame on deck, with all hands mustered to witness the flogging (see Figure 3.3). Flogging was an occupational hazard for sailors, often dealt out by harsh captains with little restraint. It was largely considered part of the initiation of sailors, 'who prided themselves on their courage and toughness, [and] felt profound shame if they were ever made to appear less than heroic'. ${ }^{5}$ If Millward acquired his taumi prior to flogging, it would have been on display during this disciplinary encounter. Its visibility would have been important in imparting a message to the Tahitians whom Bligh tells us were present and deeply distressed by the flogging. It may also have fuelled Millward's courage. As Blanchard suggests, a tattoo acts as 'a form of exo-skeletal defence: it can serve as a charm protecting the tattooee or giving him or her special benefits in the immediate environment'. ${ }^{56}$ The disfigurement caused by flogging occurred within the same zone as the apotropaic capacity of tatau, the skin. Even 'dressed' as a warrior, Millward was no match for the brutal British Navy. Via the act of flogging,

52 Bounty, Log, 13 Feb 1789, ADM 55/151, TNA).

53 For a discussion of the exchange of goods and curiosities, see J Newell, 'Exotic Possessions: Polynesians and their Eighteenth-Century Collecting' (Journal of Museum Ethnography, vol 17, 2005, pp 77-88).

54 Gell, 1993, p 101; J White, 'Marks of Transgression: The Tattooing of Europeans in the Pacific Islands', in Thomas, Cole \& Douglas, 2005, p 77.

55 Isaac Land, War, Nationalism, and the British Sailor, 1750-1850, Basingstoke \& New York, Palgrave Macmillan, 2009, p 38.

56 M Blanchard, 'Post-Bourgeois Tattoo: Reflections on Skin Writing in Late Capitalist Societies', in L Taylor (ed), Visualising Theory: Selected Essays from the VAR 1990-1994, New York \& London, Routledge, 1994, p 288. 
Bligh issued a strong physical and visual reassertion of naval power and there was a performative element to Millward's lashes that would not be lost on those who spoke another language.

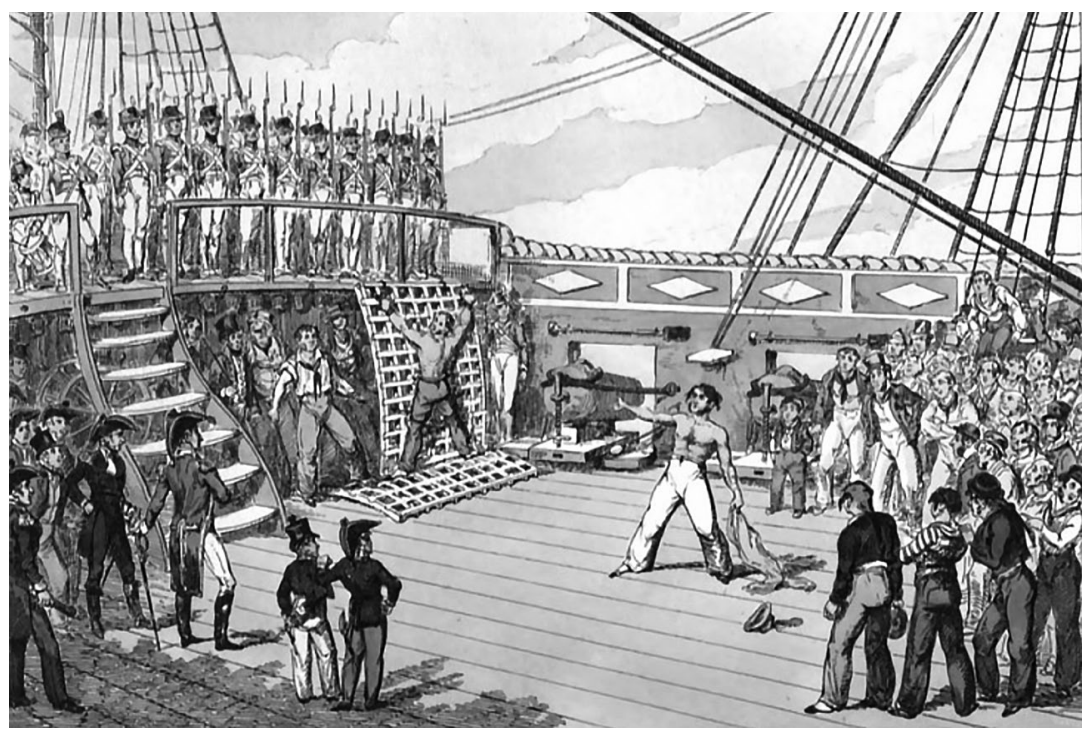

Figure 3.3. George Cruikshank, $A$ Point of Honor.

Source: Old Sailor \& G Cruikshank (1826).

If we consider this alternative, that Millward engaged in his tatau sometime after his final flogging, then his adoption of warrior iconography could be read as a none too subtle statement of Tahitian alliance and a gesture of defiance toward the Navy. Unfortunately, no record has come to light as to when Millward acquired his unusual tatau. Whatever the timescale, however, in his choice of tatau Millward transcended the role allocated to him on board the Bounty and attempted a form of social leapfrogging. He allied himself with imagery of status and power that was far removed from his shipboard role as an able seaman. ${ }^{57}$ This was not done exclusively

57 The wreck of the Bounty was excavated in 1997 by members of the Pitcairn Project, a team of maritime archaeologists from James Cook University who extensively surveyed the wreck site and the island. It is interesting to note that, amongst the items salvaged from the wreck, was a pearl-shell gorget of Polynesian workmanship. Four Aitutaki Islanders presented Bligh with a large mother-ofpearl gorget with a suspension cord of human hair when he came upon their island not long before the mutiny. However, Erskine attributes this find to the crew and their collection of 'curios' (Nicholas Erskine, 'Reclaiming the Bounty', Archaeology, vol 52, no 3, 1999a, pp 34-43). That Millward went so far as to have himself tattooed with the image of a taumi suggests the crew's engagement with the Tahitian material culture was more nuanced than the ad hoc collection of 'curios'. See Newell (2005) for sailors' collecting practices. 
through tatau, which signified the deserters' commitment to Tahitian life; the choice of taio also had an impact on the sailors' role on the Island. Bligh seemed unable to describe the markings of the mutineers unless they fell within a recognisable Western canon. Hearts, dates and French or Latin mottos posed no problem for his descriptive powers, but he was at a loss to fully describe the indigenous marks. He made no attempt to describe Peter Heywood's 'curious' Tahitian designs but does mention his Manx triskelion. The only tatau he named was Millward's taumi which Bligh could recognise because he had previously received such a breastplate as a gift - and the star on the left breasts of Christian, Isaac Martin, Edward Young and Morrison. The log of the Bounty is full of rich ethnographic description but Bligh failed to mention tatau - either amongst the Islander population or amongst the crew. The fact that Fletcher Christian acquired tatau and, as master's mate, he and Bligh interacted regularly and often dined together, make it surprising that Bligh makes no reference to the practice. Greg Dening suggests the amount of space both the crew and Bligh had on board was compromised by the boat's adaptation into a floating greenhouse and that Bligh's quarters may have been separated from those of the crew only by a canvas sheet. ${ }^{58}$ This would have led to an unusual level of physical intimacy between captain and crew, and yet he makes no attempt to fully describe their markings, nor to record the practice from an ethnographic point of view. This in itself is not unusual. Ira Dye noted a similar phenomenon with regard to Cook who, although he recorded the practice of tatau, did not compare it to any marks adopted by his crew. But, as Dye suggests, Cook was 'reporting on exotic Polynesian customs not the familiar habits of the British sailor'. 59

The extended stay in Tahiti allowed an unprecedented level of sustained cultural immersion for the crew of the Bounty. Friendship bonds were formed, lovers were taken and discarded, heiva were witnessed, and the full gamut of Tahitian life was experienced - but from a totally alien perspective. For the crew of the Bounty the skin became a contact zone, a social space 'where disparate cultures clash, and grapple with each other'. ${ }^{60}$ Out of that grappling came a new skin, a different person. The skin proclaims experience and skin marked by tatau was a clear indicator of 'South Seas' experience. An anchor, for example, might mark

58 Dening, 1992, p 20.

59 Dye, 1989, p 523.

60 ML Pratt, Imperial Eyes: Travel Writing and Transculturation, London, Routledge, 1992, p 7. 
you out as a sailor, but Heywood's 'curious indigenous marks' betray a level of interaction with the Islanders that would be viewed with suspicion by the majority of the gentlemanly class back home. ${ }^{61}$ Corporal John Ledyard of the Marines on Cook's third voyage, remarked that back in England the [Tahitian] marks on my hands procure me \& my Country-men the appellation of "wild men"'. ${ }^{2}$ Amongst the sailing fraternity, tatau spoke of island living and sexual freedom and was the mark of a seasoned sailor, but, for members of the upper classes, such as Heywood's mother, it may have been a different matter altogether. Heywood wrote to her describing his appearance when apprehended on board the HMS Pandora, which was sent by the Admiralty to round-up the mutineers.

Being dressed in the country manner, tanned as brown as themselves [the Tahitians] and I tattooed like them in the most curious manner, I do not wonder at their [the Pandora crew] taking us for natives.

His sense of boyish pride is tempered with 'I was tattooed, not at my own desire, but theirs ${ }^{63}$ Heywood's description of being mistaken for a Tahitian betrays the ability of the skin to be a register of similarity and difference. When his pale European skin became tanned and familiar tattoo symbols were mixed with Tahitian designs, boundaries became blurred. By acquiring a mixture of Tahitian and Western tattoos, mutineers such as Heywood, Stewart and Morrison became amorphous beings in the eyes of their compatriots.

Bligh did not mention Heywood having tatau; rather, he is described as 'very much tattooed'. Heywood refers to himself as having curious tattoos 'like them'. The implication here is that these were indigenous designs as worn by the Tahitians; standard sailor tattoos of the era would not appear curious to fellow Europeans on the HMS Pandora. In addition to this, Bligh's letter tells us that on Heywood's right leg 'is tatowed the Legs of Man as the impression on that Coin is. At this time he had not done growing and Speaks with the Isle of Man Accent'. The three-legged Manx symbol represented the stability and robustness of the Manx character (see Figure 3.4). That Heywood should choose such distinctly nationalistic

61 There were examples of 'gentlemanly' tattooing, such as those on the skin of Sir Joseph Banks and Sydney Parkinson, but these were upon the arms and therefore discreet enough to be covered by the clothing of the day. Kuwahara tells us that Banks made no mention of being tattooed himself (2005, p 47).

62 Kuwahara, 2005, p 47.

63 Tagart, 1832, p 82. 
iconography shows his affinity with his homeland. In doing so he was not solely choosing to define himself vocationally as Midshipman Heywood but as someone anchored within a terrestrial identity as well. His tattoo and tatau acted as a map of his travels, marking him out as a sailor, an adventurer and a proud Manxman. Even if the reasoning behind the voyage of the Bounty was largely mercantile (breadfruit would produce cheap food for slaves in the West Indies), it was sanctioned by the Royal Society and led by Sir Joseph Banks himself. With the addition of two dedicated botanists, one a veteran of all three Cook voyages (David Nelson), it had all the trimmings of a voyage of discovery. ${ }^{64}$ Whilst the majority of their maritime colleagues were engaged in trade or warfare, the crew of the Bounty were embarking on a voyage to the edges of the known world. To these sailors, their tatau were the stamp of experience and proof of their adventures.

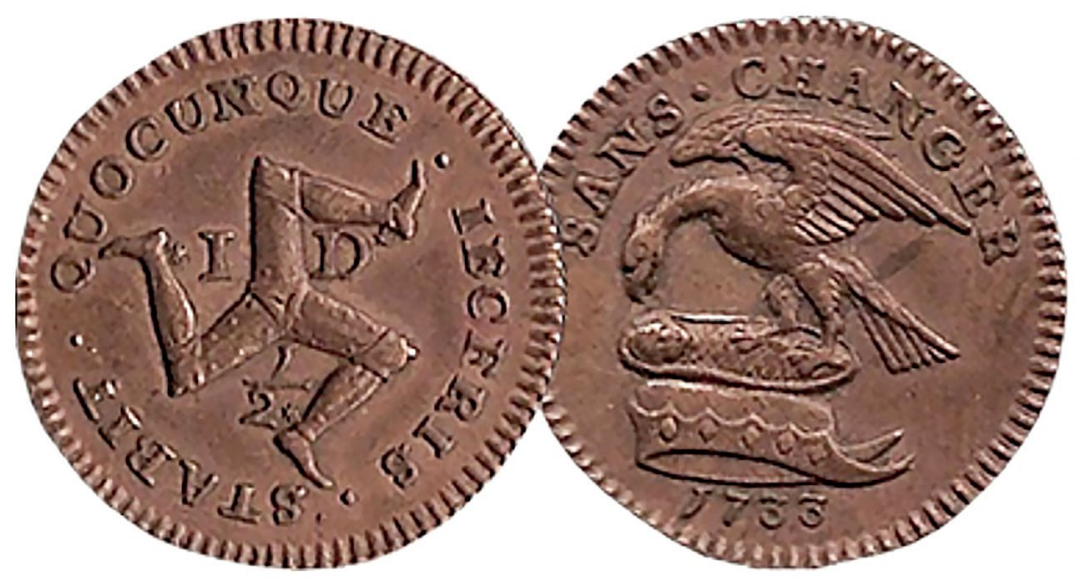

Figure 3.4. The triskelion emblem, on a Manx coin dating from 1733. Source: (c) Paul Richards, CoinQuest.com.

Just as Heywood's triskelion offers us scope for analysis, likewise, Morrison's Order of the Garter tattoo can be read as a revealing choice. The Order was founded by King Edward III in 1348 and consisted of 25 knights, of aristocratic rank, chosen as a mark of Royal favour. The insignia of the Order became increasingly elaborate over the centuries and, by Morrison's day, it included a garter with the motto embroidered or bejewelled upon

64 Wahlroos suggests that Morrison accepted a career demotion from his previous role as midshipman to the lesser post of boatswain's mate on the Bounty because of his desire to go the South Seas (1989, p 326). 
it; a gold collar with badge depicting St George and the Dragon; a broad riband; and the star, an eight-pointed silver badge depicting the cross of St George, surrounded by a depiction of the Garter. Drawing from this elaborate regalia, Morrison's tattoo took the form of the garter, wrapped around his left leg and inscribed with the Order's motto. It is unimportant whether Morrison acquired this tattoo prior to the voyage, or on the Island using indigenous skill; what matters is what it says about him. Morrison was a 28-year-old boatswain's mate, not a knight of the realm. That he chose a tattoo of a distinctly British institution, an ancient order of chivalry sanctioned directly from the Crown, hints at a proud patriotic streak, or a profound sense of irony. As a sailor in the Royal Navy he was on the lower rungs of the famously hierarchical Georgian society, and yet his tattoo spoke of an allegiance to the highest rungs of power and influence. By adopting the regalia of the aristocrat he would never be, there was a sense of aping one's betters.

Morrison also sported a star tatau on his left breast, a motif that he shared with Christian, Stewart and Martin. This star tatau, also adopted by Cook's crew onboard HMS Resolution, was used to identify the arioi elite from other Islanders. ${ }^{65}$ As Midshipman John Elliot explained:

All our mess conceived the idea of having some mark put upon ourselves, as connecting us together, as well as to commemorate our having been at Otaheite. For which purpose we determined on having a compleate Star drawn then tattowed with black, the same way as the Natives are tattowed, upon our left Breast, and painful as this operation was, we all underwent it, and have each a very handsome Black Star on our left Breast, the size of a Crown Piece. ${ }^{66}$

Cook's crew used the star tatau in a commemorative capacity as a memento of their voyage and their shared experiences. We do not know the exact reasons for its adoption by the Bounty crewmen - multiple readings are possible and all are conjecture, but that the motif appears on the bodies of the four sailors suggests a viral tendency of mark-making amongst the crew. Midshipman Elliot tells us the star tatau soon spread throughout the wider crew of the Resolution. There is no reason why this would not be the case on the Bounty; it was, after all, a distinguishing vocational motif of the Euro-American seafaring community but with the added

65 White, 2005, p 74.

66 Elliot (1773) in White, 2005, p 74. 
cross-cultural appeal of being a Tahitian tatau ${ }^{67}$ The sharing of this star motif between crew mates suggests an indelible bond, allying them to each other and, in its capacity as a vocational marker, reaffirming the sense of belonging to a wider seafaring collective; as a tatau, it associated them with an elite Island class and it therefore acted as a multipurpose signifier. As Bligh states, Christian was one of the first to move ashore and one could question how far the adoption of a design such as this and his taomaro helped to ease the shift of allegiance from ship to shore at a time of uncertainty in the face of an unknown culture. ${ }^{68}$ That this indigenous design, with its cosmological and societal meanings, was adopted by the crew confirms it as a shared memento and a vocational marker. In undergoing the painful process of tattooing, they cemented the bonds of masculinity forged in the fo' $c^{\prime} s^{\prime} l e^{69}$ and affirmed the collective sense of sailor unity. Where Morrison's Order of the Garter tattoo speaks of individuality, the star tatau speaks of collective belonging and memory.

The tattoos of dates - such as those of Joseph Coleman, Thomas Ellison and Young - can clearly be read as chronological markers, but also mementos of experiences. Ellison's tattoo commemorates the Bounty's first sighting of Tahiti on 25 October 1788. By permanently altering himself, he used the date to define himself as separate from the person he was before. His tattoo reflected a momentous event in his life. Ellison's (likely) use of indigenous skill to impart an alphanumeric tattoo rather than a Tahitian tatau extends and complicates our understanding of the sailor/tabu'a interaction. Considering the ebb and flow of design-sharing between Islanders and sailors, and the very obvious skill of the Tahitian tatau priests, it is unlikely that Ellison would have asked a crewmate to act as tattooist when he could draw on the prodigious talent of the Tahitians. His choice of numbers and letters as opposed to imagery is interesting as he was illiterate at the time of embarkation. Bligh had given instructions to his clerk John Samuel to teach the boy 'Writing and Arithmetick' and stated that 'Tom Ellison is improving and will make a very good seamen [sic] ${ }^{70}$ By tattooing himself with the alphabetised date (rather than numeric such as Coleman's 5-7-77) and his full name rather than just initials, Ellison was clearly displaying his hard-earned literacy for all to see.

67 White, 2005, p 74.

68 Bounty, Log, 10 Oct 1788, ADM 55/151, TNA.

69 Fo'c'sle: the forward part of a ship below the deck, traditionally used as the crew's living quarters.

70 Alexander, 2003, p 270. 
Young's and Coleman's tattoos depicted dates accompanied by a heart, a motif that was also tattooed on Stewart. The heart, which is today considered to be a feminine motif, occurs relatively often in Dye's data set, accounting for 201 (8.5 per cent) of the total number of tattoos recorded. ${ }^{71}$ Amongst the Bounty mutineers, these hearts were the only recognisable symbols of love and acknowledgement of domestic relations left behind. As Newman suggests:

Tattoos recorded connections with people and communities ashore, they functioned as deeply gendered badges of professional identity, proclaiming those who worked under harsh and dangerous conditions in a world from which women were almost completely absent. ${ }^{72}$

Bligh wrote in his log that 'every night I order all the natives on shore, except the women as soon as the sun is down'. One could therefore suggest that the bonds formed on the outward voyage in an exclusively male environment were reconstituted on arrival by the introduction of women into the fo' c's'le. ${ }^{73}$ By marking themselves with symbols of love, the sailors acknowledged relationships elsewhere and made reference to a life outside of the ship, either at home or on shore. They were not just sailors: they were husbands, lovers, brothers or family men. While it was common practice for older hands to tease younger crew for their attachments to women left behind at home, it would be a brave man who teased dangerously violent troublemaker Quintal for (re)naming his Tahitian partner after his mother, who died when he was a boy. The knowledge that each of his Tahitian children were named after his English relatives betrays an attachment to the memory of a family far away that sits awkwardly with the image of an aggressive, abusive drunk. He was the first to be flogged aboard the Bounty for insolence and contempt, and the man who attempted to deny Bligh the compass after forcing him and his men into the launch boat, an act that would have greatly compromised their chances of survival..$^{74}$

The issue of naming, renaming and owning Polynesian women is pertinent within the Bounty story. Women were taken as consorts either voluntarily or violently on Tahiti, Tubua'i and Pitcairn and given European names

71 Dye, 1989, p 544.

72 Newman, 1998, p 73.

73 Bounty, Log, 27 Oct 1788, ADM 55/151, TNA.

74 Alexander, 2003, p 278. For background information on Quintal, see thepeerage.com/p15758.htm (accessed June 2018). 
pronounceable to the English tongue. This act of renaming disassociated them (if only orally) from the Tahitian lineages that were discernible in their Polynesian names. ${ }^{75}$ It is unclear how far the mutineers appreciated the genealogical importance of the women's Polynesian names, and the renaming of their lovers either equates to the endearing bestowal of a nickname or an oppressive act of social control. That John Adams, who signed up under the name of Alexander Smith, tattooed his Tahitian lover, Teehuteatuaonoa (known as Jenny), with his alias implies an indelible mark of ownership that outstrips even the act of renaming. ${ }^{76}$ Names could be dropped as easily as adopted, as he well knew. To name is to control the description of something or, as in this case, someone, but to tattoo someone with a name is a statement of irrefutable possession. We have no knowledge of whether this was a brutal act of oppression - inking one's name into another's flesh, or if Teehuteatuaonoa voluntarily elected to bear Adams' initials as a mark of affection. That he enlisted under an alias and later reverted to his former name implies a level of subterfuge within his character and would perhaps explain why he chose to bestow his initials upon his lover, rather than on his own body.

The tattooing of oneself with initials has been likened to the use of military dog tags to preserve sailors from anonymity in death - for example, in the event of shipwreck. ${ }^{77}$ Dye's research into Seamen's Protection Certificates revealed that the majority of sailors in this group had only one tattoo and that, of these, 38 per cent were tattooed with their initials. It would seem that, for many seamen, tattooing one's initials not only represented the first tentative steps into the world of tattooing, but also acted as assertive marks of identity, a theory borne out by the bodies of Young (aged 22) and Ellison (aged 17), but bucked spectacularly by the highly ornamented bodies of Heywood (aged 17) and Quintal (aged 21). ${ }^{78}$ Considering the scale of tattooing amongst the crew and if the inking of initials upon the skin really did represent a 'gateway' tattoo preceding further skin embellishment, it is surprising that only two identified themselves by tattoos of their names or initials. The dog tag analogy is particularly apt

\footnotetext{
75 Pauline Reynolds, 'The Forgotten Women of the Bounty and their Material Heritage', paper presented at the Mãori and Pacific Textile Symposium, 10-11 th June 2011, Museum of New Zealand Te Papa Tongarewa, 2010, p 2, academia.edu/5830921/The_Forgotten_Women_of_the_Bounty_ and_their_Material_Heritage.

76 D Oliver (ed), Justice, Legality and the Rule of Law: Lessons from the Pitcairn Prosecution, Oxford, Oxford University Press, 2009, p 45.

77 Maxwell Stuart \& Bradley, 1997, p 83.

78 Dye, 1989, p 537.
} 
for nomadic populations such as soldiers and sailors, as the possibility of dying unidentified and so far from home was a real and constant threat. Death at sea would have been ever present in the minds of the Bounty sailors especially following the death of Able Seaman James Valentine on 10 October 1788. His few possessions were distributed amongst those that had cared for him 'with great care and affection' and he was buried at sea with 'all the decency in our power'. ${ }^{79}$ That he was cared for so sensitively by his crewmates acknowledged the bonds formed under such physically demanding and dangerous conditions. His carers were given his shirts, which were his only possessions. Valentine died of an infection caught whilst being bled by the surgeon for a separate complaint. Although he lacked any tattoos, and is therefore not mentioned in Bligh's letter, he is relevant here because his death highlights how the simple act of cutting the skin led to a painful and drawn out death. This was a real risk with tattooing. That the sailors knew of the extreme levels of pain and swelling tattooing caused and yet still engaged in the process indicates their commitment to redefining their bodies and the way others saw them. It could also show an appreciation of the importance of tatau to the Tahitians, and what the crew stood to gain, as Heywood explains:

It was my constant endeavour to acquiesce in any little custom which I thought would be agreeable to them, though painful in the process, provided I gained by it their friendship and esteem. ${ }^{80}$

Through their choice to engage with body modification, the crew of the Bounty took ownership of how they wished to be seen by others. With little personal space and very few belongings, tattooing was a way for 'little people' (as Greg Dening puts it) ${ }^{81}$ to assert their individuality within an institution as rigid as the British Navy. The space restrictions experienced by the sailors on the Bounty, which were by no means unique, are suggested by Bligh's need to refer to his fellow castaways to trawl their collective memories for it was they 'who were best acquainted with their [the mutineers] marks', ${ }^{82}$ suggesting an intimate knowledge of each others' bodies acquired through months of living cheek by jowl.

79 Bounty, Log, ADM 55/151, TNA.

80 Tagart, 1832.

81 Greg Dening, 'Writing, Rewriting the Beach: An Essay', in Alun Munslow \& Robert A Rosenstone (eds), Experiments in Rethinking History, New York \& London, Routledge, 2004, p 52.

8218 Aug 1789, ADM 1/1506 (9), TNA. 


\section{Conclusion}

Prior to the voyage, the sailors' details were noted by the Royal Navy in the Ships' Muster Roll. ${ }^{83}$ As the voyage progressed, details of any medical treatment, how much tobacco they consumed, who owed money and whose moral fibre had been found wanting by the action of desertion were all listed with uncompromising factuality. The bureaucratic datagathering of the Admiralty reduced men to subjectified bodies who were measured, assessed and documented. However, this documentation of the sailor reveals little, if anything, of the men trapped inside the muster rolls. In contrast, Bligh's letter offers us a springboard with which to build a visual picture of the mutineers and extract a sense of the sailor's voice within the Bounty narrative. This voice offers a counter balance to the view of a mutinous, criminal crew, as presented via their repeated cinematic personas. The bowlegged and perpetually sweaty (and, by implication, anxious) figure of Fletcher Christian is no one's idea of a Hollywood movie star (see Jolly \& Petch, Chapter 6). The letter acts as propaganda for Bligh, but nowhere in it does he criminalise the act of tattooing per se. His silence on the practice before the mutiny, raising it only after the event, implies that tattooing played a role in converting the crew to the Tahitian way of life. In contrast to the typical wanted advertisements placed in media of the era for criminals and runaways, the bodies of the Bounty mutineers were not described as wearing any clothing. They were textually laid bare for all to see, 'clothed' only in tattoos. As the literate masses viewed tattoos as marks of criminality, their presence upon the skin of the mutineers was indicative of their moral decline and untrustworthy nature.

Bligh's letter is revealing of the cross-cultural appeal of tattooing between sailors and their Polynesian hosts; however, it is not just the tattoos that build a picture of these individuals. His descriptions of the markings of vocation and disease form an enlightening picture of seafaring life in the 18th century. Injuries, 'remarkable' scars, crooked and maimed fingers, multiple scaldings and severely damaged limbs due to breakages tell of the dangers that these working men faced throughout their lives. It is interesting to note, however, that there is no mention of scars from flogging. It is hard to believe that the bodies of 18th-century sailors failed to exhibit symbols of authority such as these. William Muspratt, who received 36 lashes over two separate floggings within one month, must 
have exhibited evidence of this on his skin. Flogging was an accepted part of their vocation, and Bligh's silence in relation to any 'official' ownership of the body is revealing of just how normal this casual, if theatrical, violence was.

The body is engaged in a lifelong process of growth. It responds both to external factors such as nutrition, disease or violence, and internal ones such as the need to recast and reinvent oneself as a consequence of experience. The mutineers' experiences of indigenous contact were expressed upon their skin in the form of Tahitian tatau, but they also carried markings identifiable with their own cultures, such as hearts, dates and initials. These tattoos marked them out as sailors, practically the only group to engage in tattooing during this period. They also identified them as individuals grounded within shore-based institutions, whether geographic, such as Peter Heywood's Manx triskelion; or sociocultural, such as James Morrison's Order of the Garter. Edward Young's tattooed initials show how sailors combatted their fears about mortality through their bodies, which must have been a very real fear since marks of disease, disfigurement and injury were present in almost every member of the crew. Death was a clear occupational hazard.

The ages and ranks of the mutineers indicate that many of them had made multiple voyages during which they may have acquired the tattoos described by Bligh. Thomas Ellison, just 15 years old when he sailed on the HMAV Bounty, had already served under Bligh in the West Indies. John Mills had served in the Navy on the HMS Mediator and, presumably, to reach the rank of gunner's mate, several other vessels as well. Morrison had eight years' Royal Navy service to his name. Research suggests, however, that only Joseph Coleman whose date tattoo stemmed from an earlier voyage with Cook, had visited the Pacific. ${ }^{84}$ By acquiring more tattoos on successive voyages, such marks became 'visible indicators of long service at sea', confirming the men as 'professional' seafarers. ${ }^{85}$ That such a high proportion of the crew should be engaging in tattooing, only 20 years after the introduction of the term tatau into the English language, suggests that indelibly inking the skin was already an established practice prior to these voyages. Although it is possible they acquired (Western)

84 Alexander, 2003, p 250.

85 Newman, 1998, p 61. 
tattoos prior to arriving in Tahiti, any Tahitian tatau were acquired in the five months between the Bounty's arrival in October 1788 and departure the following April.

While carrying out their work - fetching water, food and wood - the sailors made inroads into the island itself. In doing so, their interactions with, and reflections upon, the Tahitians were made from a unique standpoint. The examples given by Bligh of buttock tattooing, the adoption of the Tahitian star motif, Millward's taumi and Ellison's date tattoo indicate that the skin acted as a transitional space allowing new island identities to be formed and crew relationships to be reconstituted through the sharing of motifs and the painful process of tattooing. ${ }^{86}$ By regarding the surface of the skin as an interface between sailor and Islander that allowed or sanctioned integration into island life, an analysis of the skin encourages a deeper understanding of sailor/Islander relations in early contact Tahiti. That three mutineers, Christian, Stewart and Quintal, who Bligh identified as the main players in the mutiny, should engage in the lengthy, repeated and highly painful activity of taomaro, a requirement for social and, perhaps more importantly, sexual relations, indicates a commitment to and understanding of their host culture. We can surmise, from Morrison's extensive ethnographic descriptions and Peter Heywood's admission of having been tattooed at the desire of the Tahitians, that tattooing, either in passive witnessing or active participation, formed a significant part of the interaction. ${ }^{87}$

86 See Greg Dening, Islands and Beaches: Discourse on a Silent Land, Marquesas 1774-1880

(Melbourne University Press, 1980, pp 20-34) for a discussion of liminal transitional spaces.

87 Tagart, 1832, p 82. 
This text is taken from The Bounty from the Beach: Cross-Cultural and Cross-Disciplinary Essays, edited by Sylvie Largeaud-Ortega, published 2018 by ANU Press, The Australian National University, Canberra, Australia. 